\begin{tabular}{|l|l|l||}
\hline \multicolumn{2}{|c|}{ PublisherInfo } \\
\hline \hline PublisherName & $:$ & BioMed Central \\
\hline \hline PublisherLocation & $:$ & London \\
\hline \hline PublisherImprintName & $:$ & BioMed Central \\
\hline \hline
\end{tabular}

\title{
Articles selected by Faculty of 1000: angiosperm relationships; chemorecpetor diversity; antibiotic-resistance genes; horizontal transfer in yeasts; centriole proteome
}

\begin{tabular}{|l|l|l||}
\hline \multicolumn{2}{|c|}{ ArticleInfo } \\
\hline \hline ArticleID & $:$ & 3516 \\
\hline \hline ArticleDOI & $:$ & $10.1186 /$ gb-2005-6-8-339 \\
\hline \hline ArticleCitationID & $:$ & 339 \\
\hline \hline ArticleSequenceNumber & $:$ & 21 \\
\hline \hline ArticleCategory & $:$ & Paper report \\
\hline \hline ArticleFirstPage & $:$ & 1 \\
\hline \hline ArticleLastPage & $:$ & 3 \\
\hline \hline & & RegistrationDate : 2005-7-14 \\
\hline ArticleHistory & $:$ & OnlineDate $\quad: 2005-7-14$ \\
\hline \hline ArticleCopyright & $:$ & BioMed Central Ltd2005 \\
\hline \hline
\end{tabular}




\begin{tabular}{|l|l|l||}
\hline ArticleGrants & $:$ & \\
\hline \hline ArticleContext & $:$ & 130596688 \\
\hline
\end{tabular}

The Author(s)

\section{Summary}

Angiosperm relationships; chemorecpetor diversity; antibiotic-resistance genes; horizontal transfer in yeasts; centriole proteome

\section{Angiosperm relationships}

Identifying the basal angiosperm node in chloroplast genome phylogenies: sampling one's way out of the Felsenstein zone. Leebens-Mack J, Raubeson LA, Cui L, Kuehl JV, Fourcade MH, Chumley TW, Boore JL, Jansen RK, Depamphilis CW. Mol Biol Evol 2005, June 8.

For the Faculty of 1000 evaluation of this article please see: http://genomebiology.com/reports/F1000/ gb-2005-6-8-339.asp\#Leebens-Mack

\section{Chemorecpetor diversity}

High genetic diversity in the chemoreceptor superfamily of Caenorhabditis elegans . Stewart MK, Clark NL, Merrihew G, Galloway EM, Thomas JH. Genetics 2005, 169:1985-1996.

For the Faculty of 1000 evaluation of this article please see: http://genomebiology.com/reports/F1000/ gb-2005-6-8-339.asp\#Stewart

\section{Antibiotic-resistance genes}

Microarray-based detection of 90 antibiotic resistance genes of gram-positive bacteria. Perreten V, Vorlet-Fawer L, Slickers P, Ehricht R, Kuhnert P, Frey J. J Clin Microbiol 2005, 43:2291-302.

For the Faculty of 1000 evaluation of this article please see: http://genomebiology.com/reports/F1000/ gb-2005-6-8-339.asp\#Perreten 


\section{Horizontal transfer in yeasts}

Contribution of horizontal gene transfer to the evolution of Saccharomyces cerevisiae . Hall C, Brachat S, Dietrich FS. Eukaryot Cell 2005, 4:1102-1115.

For the Faculty of 1000 evaluation of this article please see: http://genomebiology.com/reports/F1000/ gb-2005-6-8-339.asp\#Hall

\section{Centriole proteome}

Proteomic analysis of isolated chlamydomonas centrioles reveals orthologs of ciliary-disease genes. Keller LC, Romijn EP, Zamora I, Yates JR, Marshall WF. Curr Biol 2005, 15:1090-1098.

For the Faculty of 1000 evaluation of this article please see: http://genomebiology.com/reports/F1000/ gb-2005-6-8-339.asp\#Keller 